\title{
Cellular Differences in Agrobacterium Susceptibility and Regenerative Capacity Restrict the Development of Transgenic Grapevines
}

\author{
Sheila M. Colby, Adrian M. Juncosa ${ }^{1}$, and Carole P. Meredith \\ Department of Viticulture and Enology, University of California, Davis, CA 95616
}

Additional index words. Vitis vinifera, adventitious shoot, regeneration, transformation

\begin{abstract}
Although grape is easily infected with Agrobacterium and plants can be regenerated routinely, it has proven recalcitrant to the recovery of transgenic plants. Anatomical and histochemical analyses of cocultivated regenerating leaf explants were used to investigate the compatibility of direct shoot organogenesis with Agrobacterium- mediated transformation. Leaves of Vitis vinifera L. cvs. French Colombard and Thompson Seedless were cocultivated with Agrobacterium tumefaciens containing a binary vector carrying kanamycin resistance (APH(3')II) and ( $\beta$ - glucuronidase (GUS) genes. Explants were cultured on shoot-inducing medium containing levels of kanamycin inhibitory to the formation of untransformed shoots and assayed for GUS expression after 2 or 4 weeks. Cells expressing GUS were most frequently observed either at the cut surface, in vascular bundles, or in inner cortical cells of the petiole, but none of these regions produce adventitious shoots. GUS expression was also frequently found on leaf laminae, where it marked the center of a zone of cross-protected cells, but unwounded lamina cells never participated in shoot regeneration. Cells expressing GUS were found less frequently in the epidermal and subepidermal locations where exogenous, multicellular promeristem initiation occurred. These observations suggest that the direct shoot regeneration system used here could produce chimerally transformed plants, but is unsuitable for the routine production of uniformly transformed plants.
\end{abstract}

Transgenic grapevines have not yet been recovered by Agrobacterium- mediated transformation, although Agrobacterium infection (Martin, 1988) and adventitious shoot regeneration (Stamp et al., 1990a) can be accomplished readily. The production of transgenic plants requires that at least some transformed cells also participate in regeneration. By analyzing the distribution of Agrobacterium transformation sites and the developmental anatomy of adventitious shoot regeneration, we sought to identify in our system the cells that are susceptible to Agrobacterium transformation and those that participate in regeneration and to determine the extent of overlap, if any, between these two sets of cells. Our overall objective is to develop a method to obtain transgenic grapevines.

We have previously determined the developmental sequence of direct shoot organogenesis (Colby et al., 1991). Regenerating petiole stubs of leaf explants were fixed at intervals and sectioned longitudinally (Fig. 1). After several days on regeneration medium, three distinct regions of meristematic activity became apparent. The cut surface of the petiole underwent wound meristem divisions and tannin deposition, after which no further development occurred in this region (Fig. 1, stage II). New vascular bundles extended from pre-existing vascular bundles to an organogenic region in which rapid periclinal divisions resulted in nodular structures (Fig. 1, stage II), some of which later became adventitious leaves (Fig. 1, stage III). Promeristems also arose in the organogenic region (Fig. 1, stage II), and with the development of vascular strands and true leaf primordia, many promeristems became adventitious shoot meristems (Fig. 1, stage III).

Received for publication 28 June 1990. Supported by the American Vineyard Foundation, the California Raisin Advisory Board. and the California Table Grape Corn-mission. We thank John Harada for helpful comments on the manuscript and Leslie Randall for artwork. The cost of publishing this paper was defrayed in part by the payment of page charges. Under postal regulations, this paper therefore must be hereby marked advertisement solely to indicate this fact.

'Current address: EIP Assocs., 1401 21st Street, Suite 400, Sacramento, CA 95814.
The specific objectives of the present study were to determine the distribution of cells susceptible to Agrobacterium infection and to estimate the likelihood that any of these cells would contribute to a promeristem. By analyzing the location of cells expressing $\beta$ - glucoronidase genes (GUS) in explants that regenerate in the presence of kanamycin in the context of the developmental anatomy of shoot regeneration, it was possible to infer the sites of transformation events in the initial explants and the fate of transgenic cells in adventitious organs. Our hypothesis is that only chimerally transformed promeristems can arise from a single transformation event, since epidermal and subepidermal cells jointly contribute to an initiating promeristem.

\section{Materials and Methods}

Agrobacterium vector. We employed the super-virulent disarmed Agrobacterium tumefaciens strain EHA101 (Hood et al., 1986) with a binary vector carrying an aminoglycoside phosphotransferase II [APH(3')II] gene with a cauliflower mosaic virus $35 \mathrm{~S}$ promoter and a GUS gene with a mannopine synthase promoter (Comai et al., 1990).

Cocultivation and regeneration. Leaves 2 to $8 \mathrm{~mm}$ long with a $0.5-\mathrm{mm}$ petiole stub were excised from nodal cultures of 'Thompson Seedless' (syn. Sultana) and 'French Colombard' grapes (Stamp et al., 1990a). A. tumefaciens was grown at 25C in 523 medium (Rodriguez and Tait, 1983) containing $100 \mathrm{mg}$ gentamycin/liter (Sigma, St. Louis) or $100 \mathrm{mg}$ kanamycin B sulfate/liter (IBI, New Haven, Corm. ) at pH 7.1. Bacterial cultures were spun down and resuspended $\left(\mathrm{OD}_{420}=1.5\right)$ in 523 medium containing $100 \mu \mathrm{M}$ acetosyringone (Aldrich, Milwaukee, Wis.) at $\mathrm{pH}$ 5.5. Leaves were dipped into the bacterial culture for 2 rein, blotted lightly on sterile Whatman \#2 filter paper, and placed abaxial side down on shoot-inducing medium consisting of Nitsch and Nitsch (1969) salts and vitamins, iron as in Murashige and Skoog (1962), $20 \mathrm{~g}$ sucrose/liter, $2 \mathrm{mg} 6-$ benzylaminopurine/liter, and either $7 \mathrm{~g}$ Bacto-agar (Difco, Detroit, Mich.) or $5.5 \mathrm{~g}$ Sigma Plant Tissue Culture agar/liter. After the medium was autoclave at $103 \mathrm{kPa}$ for $24 \mathrm{~min}$, acetosyringone (filter-sterilized, $0.2-\mu \mathrm{m}$ pore diameter) was added 


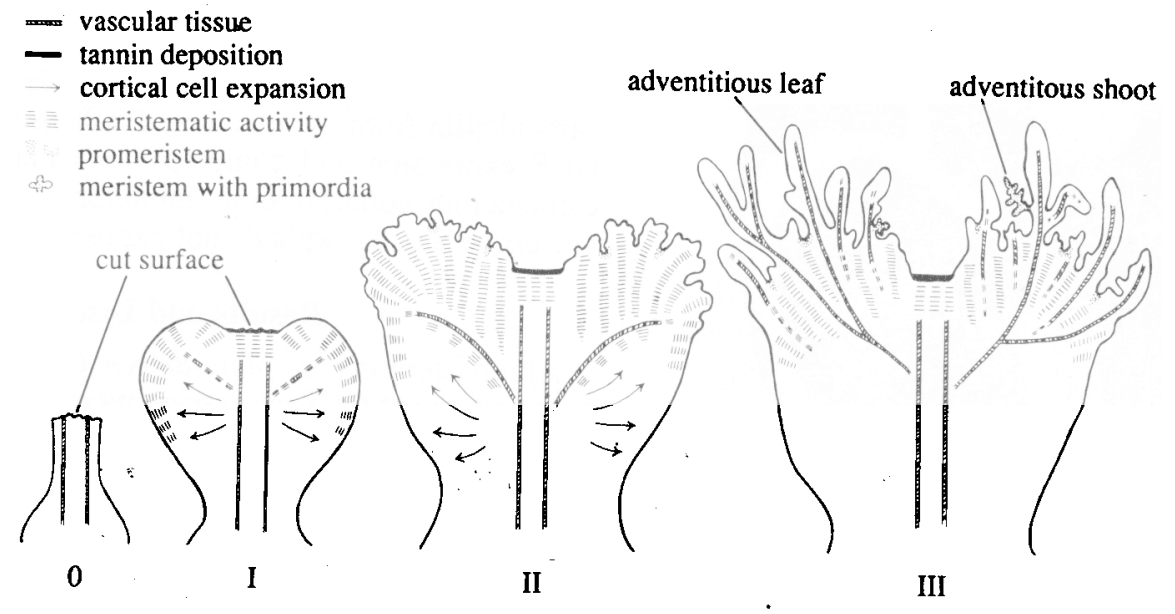

Fig. 1. Schematic'diagram of developmental sequence of direct shoot organogenesis (not to scale). In stages 0-III, explants develop at different rates, so stated ranges of days are approximate. (0) Petiole stub on day of excision. (I) Petiole stub, days 5-10, showing regions of meristematic activity. (II) Petiole stub, days 10-17, depicting early organogenesis. (III) Petiole stub, days 18-33, with mature adventitious shoots and leaves.

to a final concentration of $100 \mu \mathrm{M}$, and the $\mathrm{pH}$ was adjusted to 5.5. Twenty milliliters of medium was dispensed per $15 \times 100$ $\mathrm{mm}$ sterile, plastic petri dish. The cultures were sealed with parafilm $\mathrm{M}$ and incubated at $25 \pm 1 \mathrm{C}$ with a $16-\mathrm{hr}$ photoperiod (40 $\left.\mathrm{\mu mol} \cdot \mathrm{s}^{-1} \cdot \mathrm{m}^{-2}\right)$.

Explants were transferred after 2 days to shoot-inducing medium prepared as above but with the omission of acetosyringone and the addition of $500 \mathrm{mg}$ carbenicillin/liter (Roerig, N.Y.) and 3 to $7 \mathrm{mg}$ kanamycin/liter and with a $\mathrm{pH}$ of 5.7, adjusted before autoclaving. The kanamycin concentrations used allowed some development to occur in the cut surface, new vascular, and in organogenic regions of petiole stubs that were not cocultivated, but were sufficient to inhibit organ initiation. After 1 week, explants were transferred to fresh medium of the same composition, but with $250 \mathrm{mg}$ carbenicillin/liter. Subsequent transfers were made every 2 weeks. Shoots elongating to $5 \mathrm{~mm}$ were excised and transferred to half-strength Murashige and Skoog medium (1962) containing $2 \%$ sucrose, $1.0 \mathrm{mg}$ indole3-acetic acid/liter, pH 5.7, and either $7 \mathrm{~g}$ Bacto-agar or $5.5 \mathrm{~g}$ Sigma Plant Tissue Culture agar/liter, for rooting and further shoot elongation (Stamp et al., 1990a).

Histochemical assays. Expression of GUS was analyzed in regenerating petiole stubs, cocultivated leaf laminae, and leaves from adventitious shoots. To allow penetration of 6-bromo-4chloro-3-indolyl-glucuronide (X-Gluc), regenerating petiole stubs were longitudinally hand-sectioned with a razor blade under a stereomicroscope into 0.5 - to $1.0-\mathrm{mm}$ sections. Cocultivated laminae were cut transversely in strips $\approx 5 \mathrm{~mm}$ wide. Individual petiole stubs were killed after 2 or 4 weeks of development, scored for number and location of GUS expression spots, and compared to stained serial sections of similar stages of direct shoot organogenesis in untransformed tissue. In other experiments, adventitious buds developing on low levels of kanamycin were allowed to develop into shoots, and leaf laminae were assayed for GUS expression after 4 weeks. Leaf tips 3 to $4 \mathrm{~mm}$ long were excised from 8- to 10-mm-long adventitious shoots having two or three leaves without removing the shoot meristem. All tissues were fixed in formaldehyde 2-(4-morpholino)ethane sulfonic acid (Mes) and incubated with $0.5 \mathrm{~mm}$ X-Gluc as otherwise described by Jefferson (1987). GUS expression was observed with a stereomicroscope after $12 \mathrm{hr}$.

To differentiate GUS expression produced in transgenic plant cells from possible background GUS expression produced by
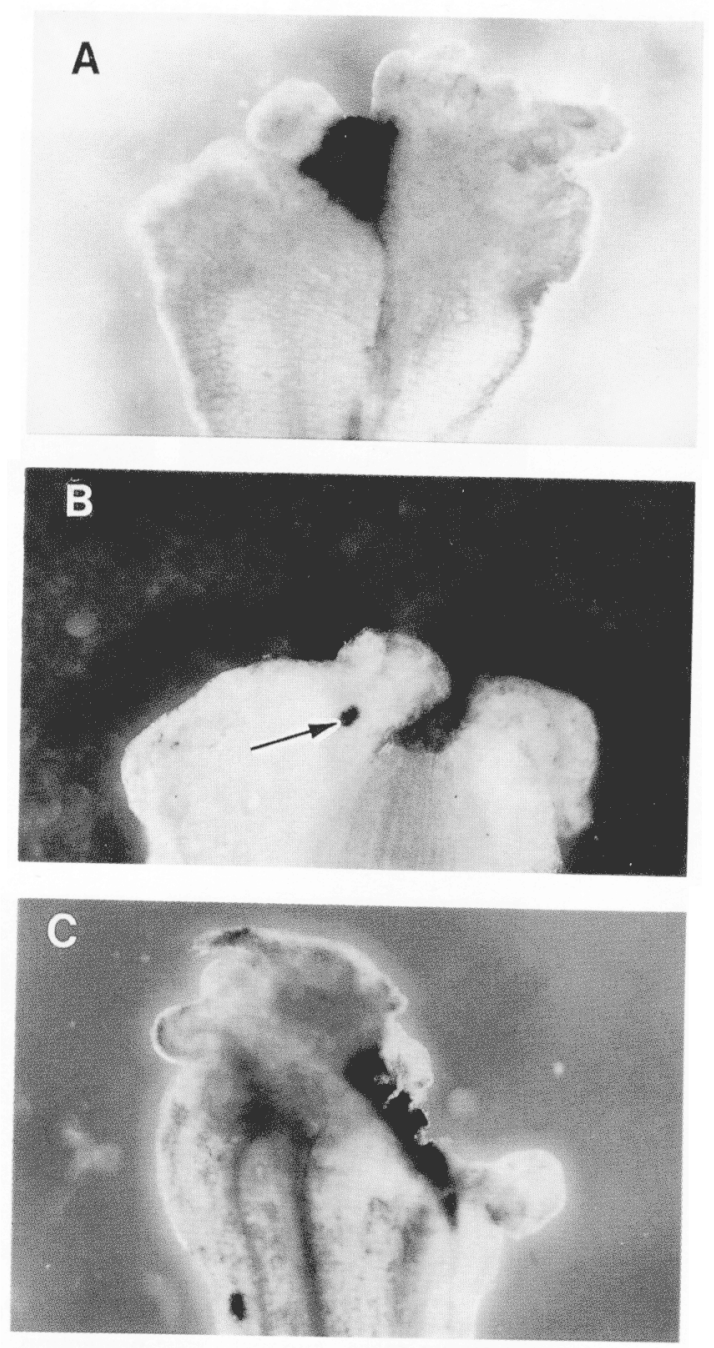

Fig. 2. Agrobacterium- and plant-driven GUS gene expression after 28 days in longitudinal hand-cut sections of petiole stubs. (A) Control explant not cocultivated with Agrobacterium. $\times 26$. (B) Explant cocultivated and cultured on carbenicillin to inhibit bacterial growth, showing a focus of dark-blue GUS expression. $\times 26$. (C) Explant cocultivated and cultured on medium without carbenicillin showing diffuse, pale-blue GUS expression. $\times 20$. 


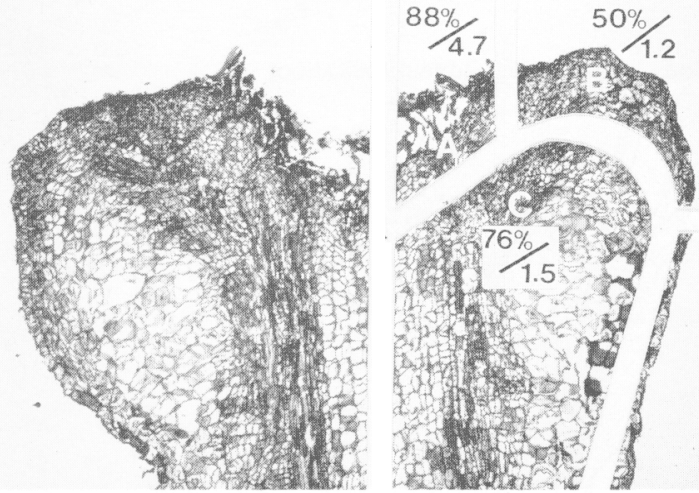

Fig. 3. Percentage of explants expressing GUS and the mean number of dark-blue foci per petiole in each of three regions for 50 explants incubated for 2 weeks on $3 \mathrm{mg}$ kanamycin/liter. $\times 40$. (A) The cut s̀urface where cells produce tannins and stop dividing. (B) The organogenic region, which includes epidermal, subepidermal, and outer cortical cells and gives rise to adventitious leaves and shoots. (C) Vascular and inner cortical cells, which do not initiate promeristems. living Agrobacterium (Jefferson, 1987), explants were assayed for expression at days 4, 11, and 21. In addition, Agrobacterium was allowed to grow in several petiole explants by omitting carbenicillin from the medium.. Explants were then assayed for GUS expression and compared to explants that had been on carbenicillin concentrations inhibitory to the growth of Agrobacterium and to explants not exposed to Agrobacterium.

\section{Results and Discussion}

Agrobacterium- vs. plant-driven GUS expression. Two distinct patterns of GUS expression were observed. Four days after cocultivation, large, diffuse, light-blue patches were observed in explants cultured on medium containing carbenicillin and kanamycin, primarily on the leaf lamina and within vascular bundles of the lamina. On day 11, foci of plant cells containing dark blue cytoplasm were first observed under a light microscope. On day 21, only dark-blue foci and no diffuse light-blue patches were observed on leaf explants. We interpret the light blue GUS expression observed in vascular bundles at days 4 and 11 as Agrobacterium- driven. This is consistent with systemic Agrobacterium infection described in grape (Lehoczky, 1968).
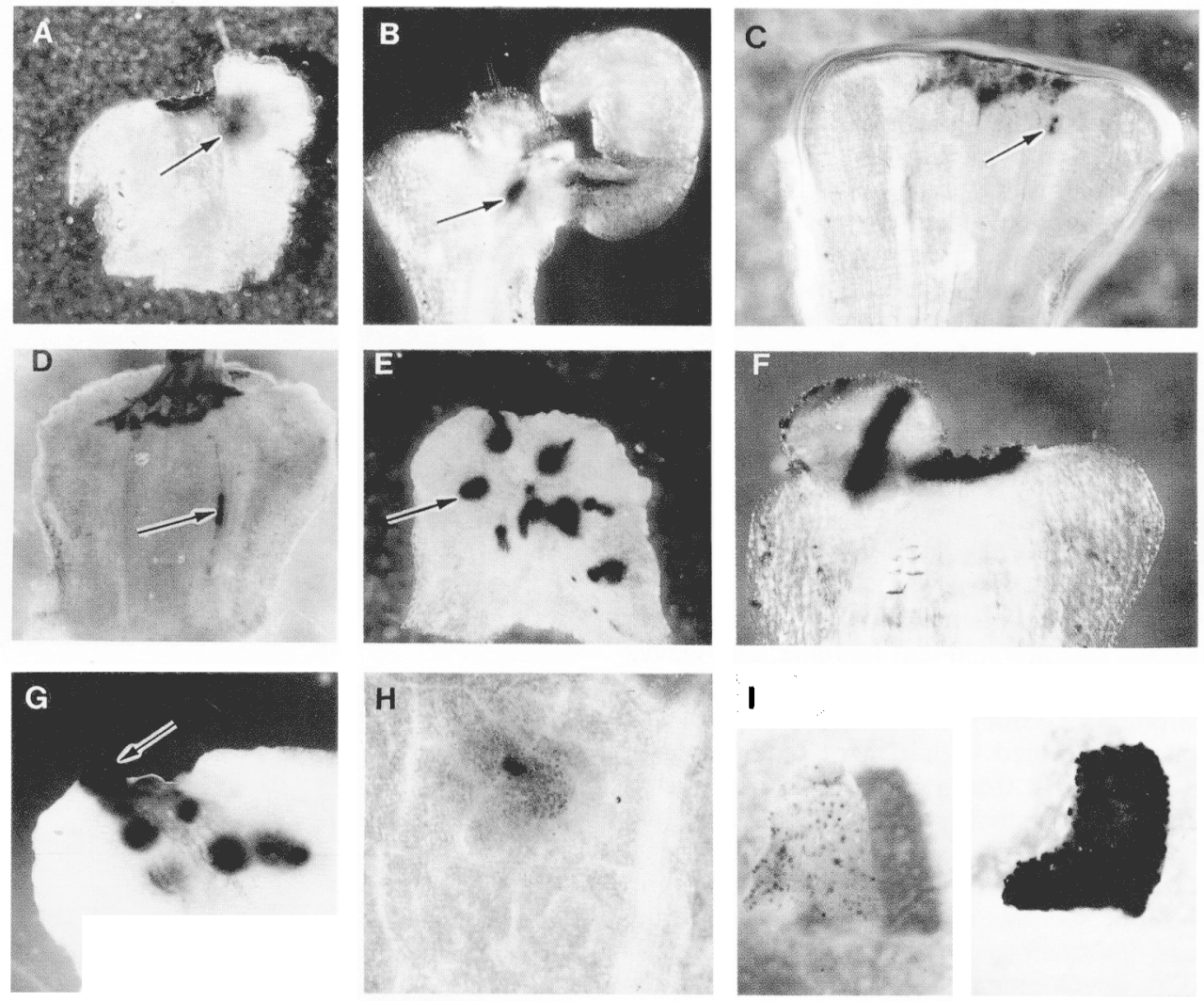

Fig. 4. GUS expression in regenerating leaf explants. (A) Petiole stub, day 31, longitudinal section (LS), showing transformed cells (arrow) near an organogenic tissue mass, suggest cross-protection. $\times 15$. (B) Petiole stub, day 31, LS, showing transformed cells (arrow) adjacent to an adventitious leaf developing on a kanamycin concentration that normally inhibits development of untransformed tissues, suggesting cross-protection. $\times 15$. (C) Petiole stub, day 31, LS, showing transformed cells (arrow) near the cut surface, which has formed nonregenerative wound response tissue. $\times 22$. (D) Petiole stub, day 31, LS, showing transformed vascular bundle cell (arrow). $\times 22$. (E) Petiole stub, day 16, oblique, showing expanded derivatives of transformed inner cortical cell (arrow). $\times 15$. (F) Petiole stub, day 31 , LS, with a lineage of transformed cells in the organogenic region extending to, but excluding, the epidermal layer. $\times 22$. (G) Petiole stub, day 20, LS, showing a transformed putative promeristem (arrow). $\times 22 .(\mathbf{H})$ Kanamycin-bleached leaf lamina, day 31 , showing a green spot with cells expressing GUS in the center. $\times 20$. (I) Leaf tips, day 45, of 'Thompson Seedless' adventitious shoots selected on 5 mg kanamycin/liter showing uniform GUS expression (right) and control lacking expression (left). $\times 18$. 
In a separate experiment, petiole explants were either cocultivated and incubated with or without carbenicillin or not exposed to Agrobacterium. Explants were assayed for GUS expression after 4 weeks. No blue areas were observed in petioles not exposed to Agrobacterium (Fig. 2A). In cocultivated explants incubated with carbenicillin, GUS gene expression appeared as sharply defined, dark-blue foci (Fig. 2B). However, in petiole explants grown without carbenicillin to inhibit the growth of Agrobacterium, large areas of the explant were diffuse light blue (Fig. 2C).

We also observed lineages of dark-blue cells similar to those observed by Finnegan et al. (1989), but we never observed diffuse light-blue cell lineages. Since it is unlikely that Agrobacterium would preferentially surround all derivatives of a particular cell, we interpret the dark-blue lineages as plant cells that were stably expressing the GUS gene. We conclude that the large patches of diffuse light blue represented Agrobacterium- driven GUS expression and the small, sharply defined foci of dark blue were GUS expression from transgenic plant cells. We cannot exclude the possibility that some of the diffuse light blue observed at day 4 was due to transient plant GUS expression (Janssen and Gardner, 1990); however, all assays discussed below were conducted after a minimum of 2 weeks to ensure that only dark-blue foci were considered in further analyses.

GUS expression in regenerating petioles. GUS expression was observed in a mean of $66 \%$ of the petiole stubs $(41 \%$ to 97\% in five experiments) and in three regions: cut surface, inner vascular and cortical, and organogenic. The results of one experiment, in which almost every explant exhibited some GUS expression, are summarized in Fig. 3.

Occasionally some tissue or an organ developed from apparently untransformed cells in the presence of a normally inhibitory kanamycin concentration (Fig. 4 A, B). Cross-protection from transformed cells might account for this observation, perhaps by a reduced kanamycin concentration localized around transformed cells that detoxify the antibiotic as it moves through them .

Transformed cells were observed most frequently in the cut surface, internal vascular, or inner cortical regions of the petiole stub (Fig. 3). Derivatives of a transformed cell at the cut surface (Fig. 4C) always formed wound-response tissue, which never participated in promeristem initiation. A transformed vascular bundle cell (Fig. 4D) cannot contribute to promeristem initiation, which always occurs at the uncut surface. A large internal spot of blue (Fig. 4E) represents the greatly expanded derivatives of a transformed inner cortical cell that divided a few times. Cells in this region do not contribute to promeristems either. These three patterns of GUS expression are consistent with the hypothesis derived from our anatomical studies that transformation events at the cut surface (Fig. 5; a, a'), in vascular bundles (Fig. 5; b, b'), or in inner cortical cells (Fig. 5; c, c') do not contribute to transformed promeristems.

Transformed cells were sometimes observed in the organogenic region (Fig. 3). Within this region, the location, size, and shape of the blue cell clusters varied. Lineages of cells expressing GUS were sometimes observed to extend to, but not include, the epidermal layer (Fig. 4F). We hypothesize that these cells (Fig. 5; d'), which originated from periclinal divisions in the outer cortex (Fig. 5; d), could participate in the initiation of a chimeral but not a fully transgenic promeristem, since derivatives of both epidermal and subepidermal cells layers always contribute to an initiating promeristem.

A few organized blue structures appeared to extend to and

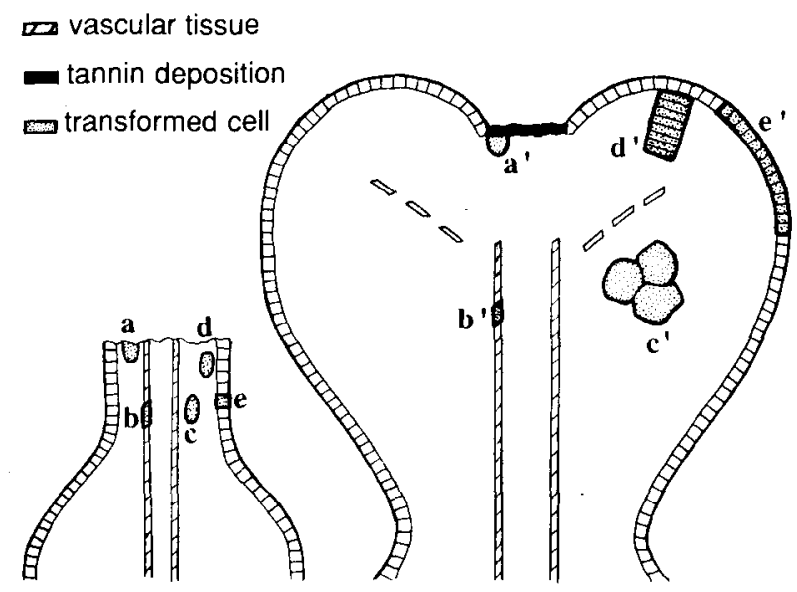

Fig. 5. Predicted fate of transgenic cells in petiole explants incubated on kanamycin (not to scale.) Derivatives of a transformed cell at the cut surface (a) would form wound response tissue $\left(a^{\prime}\right)$, which does not participate in promeristem initiation. A transformed vascular bundle cell $\left(b, b^{\prime}\right)$ would not contribute to promeristem initiation, which occurs only at the uncut surface. A transformed inner cortical cell (c) would divide a few times and its derivatives expand greatly $\left(c^{\prime}\right)$, but these transformed internal cells would not contribute to promeristems. A transformed outer cortical cell (d) would divide periclinally to a form a lineage of transformed cells $\left(d^{\prime}\right)$ in the organogenic region. Because the lineage may extend to the subepidermal layer, but not to the epidermal layer, only chimeral plants would be expected to form from these cells. A transformed epidermal cell (e) would divide anticlinally, producing a single layer of transformed cells spreading laterally $\left(\mathrm{e}^{\prime}\right)$. These cells could participate in the initiation of chimeral but not fully transformed promeristems, since both epidermal and subepidermal cells always contribute jointly to an initiating promeristem.

include the epidermal layer. In at least one case (Fig. 4G), we observed an organized mass of transgenic cells that was morphologically similar to promeristems observed in our earlier anatomical studies (Colby et al., 1991). Our predictions of the outcome of single cell transformation events do not account for this pattern of GUS expression. One possible explanation is that kanamycin selection may have inhibited cell division in a nontransformed epidermal layer, such that transformed subepidermal cells began to divide anticlinally to form a new transgenic epidermis. Bruck and Walker (1985) conducted experiments that provide convincing evidence that the epidermis initiated only once in the life of a plant. A periclinal division in a transformed epidermal cell could also account for a uniformly transformed promeristem, but we have never observed this type of division in examining thousands of epidermal cells. More consistent with observed patterns of development would be the case in which superposed epidermal and subepidermal cells, both of which were independently transformed, subsequently divided to form a promeristem. In this case, genotype and perhaps gene expression would not be uniform throughout a resulting transgenic plant.

Significantly, GUS expression in a single, laterally spreading layer of epidermal cells (Fig. 5, e'), the predicted result of anticlinal divisions of a transformed epidermal cell (Fig. 5, e), was observed on only one occasion. This result suggests that transformation of epidermal cells is very rare compared with the frequency of transformation events in the cut surface, or in vascular or cortical cells. We believe that transformed epidermal cells could contribute to a periclinally chimeral, but not uniformly transgenic, promeristem, since both epidermal and sub- 
epidermal cells always jointly contribute to a promeristem. A uniformly transgenic plant might be recovered from such a chimera, because periclinal chimeras sometimes are unstable in vitro (Skene and Barlass, 1983).

GUS expression in leaf laminae. Many dark-blue foci were observed in cocultivated leaf laminae incubated on low levels of kanamycin for 4 weeks. The number of foci per lamina ranged from zero to $>100$ within any single experiment. GUS expression in laminae was unexpected since it represented transformation of presumably unwounded cells. The reduced cuticle on leaves produced in vitro compared to greenhouse- or field-grown leaves may have facilitated infection. Transformation events occurring in these lamina cells could not produce transgenic plants because adventitious shoots do not develop from unwounded lamina cells.

On 3 to $7 \mathrm{mg}$ kanamycin/liter, foci of cells expressing GUS were surrounded by many unbleached green cells not expressing GUS on the otherwise pale, kanamycin-bleached lamina (Fig. $4 \mathrm{H})$. This pattern of GUS expression provided additional evidence for cross-protection of untransformed cells by transformed cells at low kanamycin concentrations, since the green spots were absent on laminae incubated on $20 \mathrm{mg}$ kanamycin/ liter.

GUS expression in leaf tips of adventitious shoots. On the basis of GUS expression in leaf tips sampled from shoots of many experiments, most adventitious shoots that developed in the presence of kanamycin were not transformed (Table 1). However, one leaf tip of 'Thompson Seedless' exhibited GUS expression (Fig. 41). Although the GUS expression was uniform and intense throughout. the leaf tip, we were unable to determine the pattern of GUS expression in the rest of the plant because it subsequently died.

Production of transgenic plants. The 5' MAS-GUS-MAS 3' construct was expressed in a leaf tip of an adventitious shoot, in leaf laminae, and in various cells in regenerating grape petioles. We also expected GUS expression in transgenic grape promeristems, because a similar 5' MAS-NPT II-MAS 3' construct has been successfully used to transform tobacco, tomato, and rapeseed, suggesting that the MAS promoter drives the NPT II gene in developing shoot apices of these species (McBride and Summerfelt, 1990). In addition, the 5' MAS-GUS-MAS 3' construct that we used resulted in GUS expression in transformed tobacco shoot apices (L. Comai, personal communication).

No confirmed transgenic shoots were recovered, despite repeated attempts (Table 1). Although $70 \%$ to $90 \%$ of 'Thompson Seedless' and 'French Colombard' leaf explants produce adventitious shoots (Stamp et al., 1990b), only a few epidermal and subepidermal cells per leaf explant participate in promeristem initiation. Unfortunately, Agrobacterium most frequently transforms cells at or below the cut surface of the petiole, a region that never regenerates. An average of only one transformation

Table 1. GUS expression in grape leaf tips excised from adventitious shoots derived from cocultivated leaves and regenerated on shootinducing medium containing kanamycin.

\begin{tabular}{lccc}
\hline \hline & $\begin{array}{c}\text { Total } \\
\text { explants } \\
\text { cocultivated } \\
\text { (no.) }\end{array}$ & $\begin{array}{c}\text { Shoots } \\
\text { regenerated } \\
\text { (no.) }\end{array}$ & $\begin{array}{c}\text { GUS positive } \\
\text { leaf tips } \\
\text { (no.) }\end{array}$ \\
\hline Thompson Seedless & 1650 & 78 & 1 \\
French Colombard & 4660 & 188 & 0 \\
\hline
\end{tabular}

event occurs per explant in the organogenic region, so the probability that it will coincide with a site of promeristem initiation is very low. Consequently, the expected frequency of transgenic plants is very low. The high frequency of cut surface, vascular, and inner cortical transformation events compared with the relatively rare occurrence of epidermal transformation events supports previous reports that Agrobacterium most often enters plant tissues through wound sites and not through intact epidermal cells.

It might be possible to increase transformation of regenerable epidermal cells on petiole stubs. In the present study, we employed both a supervirulent Agrobacterium strain (Hood et al., 1986; Jin et al., 1987) and acetosyringone (Stachel et al., 1985) to maximize infection. Biovar 3 Agrobacterium strains that naturally infect grape might transform at a higher frequency than the Biovar 1 strain employed in this study. Alternatively, microprojectile bombardment might be used to direct DNA to epidermal and subepidermal cells in the organogenic region.

A few blue spots included cells in both the epidermal and subepidermal layers, the region that initiated promeristems, suggesting that transgenic plants could be produced with this system. However, we believe that kanamycin selection inhibited the further development of chimeral or uniformly transformed promeristems. Adventitious shoot development on petiole stubs is polar and dependent on the presence of the leaf lamina (Stamp et al., 1990b). Kanamycin inhibition of untransformed lamina cells may affect regeneration similarly to lamina removal by reducing or eliminating the supportive influence of the lamina on shoot development from transformed cells.

Furthermore, the coordinated development within the petiole stub (Fig. 1; stage I) preceding organogenesis is an important prerequisite to shoot formation. The effect of kanamycin on the development of untransformed nodular bumps or new vascular bundles could alter patterns of initiation or development in transformed promeristems. Specifically, promeristems most frequently form in or near grooves between nodular bumps in the organogenic region (Colby et al., 1991). Because nodular bump formation is reduced in kanamycin-treated petiole stubs, promeristem initiation may also be reduced. In addition, in the absence of kanamycin, developing shoot meristems are linked to pre-existing vascular bundles by new vascular bundles. If these untransformed developing vascular bundles are functionally important, kanamycin inhibition of their development might limit the further growth of transformed adventitious shoots.

The developmental considerations elucidated in both the previous anatomical study (Colby et al., 1991) and the present work suggest the need for an improved strategy for grape transformation and regeneration. Alternative regeneration systems by which plants originate from single cells are desirable to avoid the production of transgenic chimeras, like those obtained by Baribault et al. (1990), that might result from the direct shoot organogenesis system employed in our study. Grapevines regenerated by somatic embryogenesis have a single-cell origin (Krul and Worley, 1977), as is the case in many other species (Raghavan, 1986). Somatic embryogenesis can be induced from several grape tissues and genotypes (Mullins and Srinivasan, 1976; Rajasekaran and Mullins, 1979; Stamp and Meredith, 1988).

Histochemical assays did not definitively differentiate between transient and stable GUS expression. In addition, some transformed cells that did not express detectable amounts of GUS may have been present. We assayed petiole explants several weeks after cocultivation to avoid scoring transient GUS 
gene expression (Jannsen and Gardner, 1990). We frequently observed cell lineages expressing GUS extending in the direction of growth, suggesting stable integration of the GUS gene. A more conclusive determination of genetic stability and additional molecular evidence for transformation were not critical to the present analysis of the distribution of transformation events in regenerating grape explants.

Developmental features of in vitro regeneration can significantly affect the production of transgenic plants. Explant type, medium composition, culture conditions, and plant genotype determine the unique developmental characteristics of each regeneration system. In our grape leaf regeneration system, we identified cells that initiate promeristems, by anatomical study, and cells that are susceptible to Agrobacterium, by cocultivation with subsequent GUS analysis. With this dual approach, we were better able to understand difficulties we have encountered in the development of a grape transformation system. Our results suggest that the cocultivation and direct shoot regeneration system employed here could produce some chimerally transformed plants, but is unsuitable for the routine production of uniformly transformed plants. Similar studies should prove useful in improving other recalcitrant transformation systems.

\section{Literature Cited}

Baribault, T.J., K.G.M. Skene, P.A. Cain, and S. Scott. 1990. Transgenic grapevines: regeneration of shoots expressing $\beta$-glucuronidase. J. Expt. Bot. 41:1045-1049.

Bruck, D.K. and D.B. Walker. 1985. Cell determination during embryogenesis in Citrus jambhiri II. Epidermal differentiation as a onetime event. Amer. J. Bot. 72:1602-1609.

Colby, S.M., A.M. Juncosa, J.A. Stamp, and C.P. Meredith. 1991. Developmental anatomy of direct shoot organogenesis from leaves of Vitis vinifera L. Amer. J. Bot. (In press.)

Comai, L., P.M. Moran, and D. Maslyar. 1990. Novel and useful properties of a chimeric plant promoter combining CaMV35S and MAS elements. Plant Mol. Biol. 15:373-381.

Finnegan, E.J., B.H. Taylor, S. Craig, and E.S. Dennis. 1989. Transposable elements can be used to study cell lineages in transgenic plants. The Plant Cell 1:757-764.

Hood, E.E., G.L. Helmer, R.T. Fraley, and M.-D. Chilton. 1986. The hypervirulence of Agrobacterium tumefaciens A281 is encoded in a region of pTiBo542 outside of T-DNA. J. Bacteriol. 168:12911301.

Janssen, B.-J. and R.C. Gardner. 1990. Localized transient expression of GUS in leaf discs following cocultivation with Agrobacterium. Plant Mol. Biol. 14:61-72.

Jefferson, R. 1987. Assaying chimeric genes in plants: the GUS gene fusion system. Plant Mol. Biol. Rptr. 5:387-405.

Jin, S., T. Komari, M.T. Gordon, and E.W. Nester. 1987. Genes responsible for the supervirulence phenotype of Agrobacterium tumefaciens A281. J. Bacteriol. 169:4417-4425.

Krul, W.R. and J.F. Worley. 1977. Formation of adventitious embryos in callus cultures of 'Seyval,' a French hybrid grape. J. Amer. Soc. Hort. Sci. 102:360-363.

Lehoczky, J. 1968. Spread of Agrobacterium in the vessels of the grapevine, after natural infection. Phytopath. Z. 63:239-246.

Martin, L. 1988. Genetic transformation and foreign gene expression in tissue of different woody species. MS thesis, Univ. of California, Davis.

McBride, K.E. and K.R. Summerfelt. 1990. Improved binary vectors for Agrobacterium- mediated plant transformation. Plant Mol. Biol. 14:269-276.

Mullins, M.G. and C. Srinivasan. 1976. Somatic embryos and plantlets from an ancient clone of grapevine (cv. Cabernet Sauvignon) by apomixis in vitro. J. Expt. Bot. 27:1022-1030.

Murashige, T., and F. Skoog. 1962. A revised medium for rapid growth and bio assays with tobacco tissue cultures. Physiol. Plant. 15:473497.

Nitsch, J.P. and C. Nitsch. 1969. Haploid plants from pollen grains. Science 163:85-87.

Raghavan, V. 1986. Embryogenesis in angiosperms. Cambridge Univ. Press, Cambridge.

Rajasekaran, K. and M.G. Mullins. 1979. Embryos and plantlets from cultured anthers of hybrid grapevines. J. Expt. Bot. 30:399-407.

Rodriguez, R.L. and R.C. Tait. 1983. Recombinant DNA techniques. Addison-Wesley, Reading, Mass.

Skene, K.G.M. and M. Barlass. 1983. Studies of the fragmented shoot apex of grapevine IV. Separation of phenotypes in a periclinal chimera in vitro. J. Expt. Bot. 34:1271-1280.

Stachel, S.E., E. Messens, M. Van Montagu, and P. Zambryski. 1985. Identification of signal molecules produced by wounded cells that activate T-DNA transfer in Agrobacterium tumefaciens. Nature (London) 318:624-629.

Stamp, J. and C.P. Meredith. 1988. Somatic embryogenesis from leaves and anthers of grapevine. Scientia Hort. 35:235-250.

Stamp, J.A., S.M. Colby, and C.P. Meredith. 1990a. Direct shoot organogenesis and plant regeneration from leaves of grape (Vitis vinifera L.) Plant Cell Tissue Organ Cult. 22:127-133.

Stamp, J.A., S.M. Colby, and C.P. Meredith. 1990b. Improved shoot organogenesis from leaves of grape. J. Amer. Soc. Hort. Sci. 115:1038-1042. 